PERM JOURNAL OF PETROLEUM AND MINING ENGINEERING

ВЕСТНИК ПНИПУ. ГЕОЛОГИЯ. НЕФТЕГАЗОВОЕ И ГОРНОЕ ДЕЛО

ISSN 2224-9923

Volume / Tом 20 №2 2020

http://vestnik:pstu.ru/geo/

UDC 622.276.05:620.197.3

\title{
INFLUENCE OF THE ANIONIC COMPOSITION AND ACID GAS CONTENT IN FORMATION WATERS OF PERM KRAI FIELDS ON CORROSION INHIBITOR EFFECTIVENESS
}

\author{
Aleksandr N. Ladygin \\ Perm National Research Polytechnic University (29 Komsomolsky av., Perm, 614990, Russian Federation)

\section{ВЛИЯНИЕ АНИОННОГО СОСТАВА И СОДЕРЖАНИЯ КИСЛЫХ ГАЗОВ В ПЛАСТОВЫХ ВОДАХ МЕСТОРОЖДЕНИЙ ПЕРМСКОГО КРАЯ НА ЭФФЕКТИВНОСТЬ ИНГИБИТОРОВ КОРРОЗИИ}

\section{А.Н. Ладыгин}

Пермский национальный исследовательский политехнический университет (614990, г. Пермь, Комсомольский проспект, д. 29)

Received / Получена: 25.12.2019. Accepted / Принята: 15.04.2020. Published / Опубликована: 15.06.2020

\section{Key words:}

pitting corrosion, well, hydrogen sulfide, chlorides, sulfates, bicarbonates, carbon dioxide, double electric layer, passivation, pitting potential, voltammetry, impedance spectroscopy, anions, cations, corrosion inhibitor.
Ключевые слова: питтинговая коррозия, скважина, сероводород, хлориды, сульфаты, бикарбонаты, диоксид углерода, двойной электрический слой, пассивация, потенциал питтингообразования, вольтамперометрия, импедансная спектроскопия, анионы, катионы, ингибитор коррозии.
In the course of hydrocarbon deposit development, formation water starts entering the wells over time. An increasing produced water volume has a negative impact on economic indicators of oilfield developments and leads to other hazardous consequences, such as equipment corrosion. Downhole equipment corrosion causes largest financial losses, since well accidents entail expensive repairs. Therefore, it is critical to prevent the equipment corrosion. The study considers main properties and composition of formation waters. Based on an overview of open literature sources, we analyzed the impact of $\mathrm{Cl}^{-}, \mathrm{SO}_{4}{ }^{-2}, \mathrm{HCO}_{3}{ }^{-}$anions contained in the formation waters on corrosion process kinetics at the phase interface between metal (electrode) and water (electrolyte). The study also discusses the results of researches on the influence of dissolved acid gases $\left(\mathrm{H}_{2} \mathrm{~S}\right.$ and $\left.\mathrm{CO}_{2}\right)$ on corrosion mechanisms and rates. An influence of $\mathrm{pH}$ value on the corrosion rate is considered. Contents of various salts in the formation waters contribute to the complexity of corrosion processes occurring in real conditions. Presence of aggressive environments can accelerate corrosion in some instances, but sometimes it can slow it down; this fact also affects the inhibitor protection effectiveness.

Based on laboratory analysis data, effectiveness of using the corrosion inhibitor in the formation waters with different compositions and properties is assessed. It has been established that presence of a mix of aggressive components chloride ions and hydrogen sulfide - in the formation waters causes hydrogen sulfide corrosion inhibition and reduction of chloride corrosion rate. Presence of dissolved salt ions and acid gases in the formation waters improves effectiveness of the corrosion inhibitors due to strong passive films formed on steel equipment surfaces.

При разработке залежей углеводородов в скважины со временем начинают поступать пластовые воды. Повышение объемов попутно добываемых вод негативно сказывается не только на экономических показателях разработки месторождений, но и приводит к другим опасным последствиям, к таким, например, как коррозия оборудования. Наибольший экономический ущерб приносит коррозия скважинного оборудования, так как аварии на скважинах обусловливают необходимость проведения дорогостоящих ремонтных операций. В связи с этим предотвращение коррозии оборудования является актуальной задачей. Рассматриваются основные свойства и состав пластовых вод. На основании открытых литературных источников анализируется влияние содержащихся в пластовых водах анионов $\mathrm{Cl}^{-}, \mathrm{SO}_{4}^{-2}, \mathrm{HCO}_{3}^{-}$на кинетику протекания коррозионных процессов на поверхности раздела фаз металла (электрода) и воды (электролита). Также приведены данные исследований влияния наличия растворенных кислых газов $\left(\mathrm{H}_{2} \mathrm{~S}\right.$ и $\left.\mathrm{CO}_{2}\right)$ на механизм и скорость протекания коррозии. Рассматривается влияние водородного показателя на скорость коррозии. Содержание различных солей в пластовых водах обусловливает сложность коррозионных процессов, происходящих в реальных условиях. Наличие агрессивных сред в некоторых случаях способствует ускорению коррозии, но иногда и ее замедлению, это также сказывается на эффективности ингибиторной защиты.

На основе данных лабораторных исследований проведена оценка эффективности применения ингибиторов коррозии в пластовых водах с различными составами и свойствами. Установлено, что содержание в пластовой воде смеси агрессивных компонентов - хлорид ионов и сероводорода - приводит к угнетению сероводородной коррозии, при этом скорость хлоридной коррозии тоже снижается. Наличие ионов растворенных солей и кислых газов в пластовых водах способствует повышению эффективности применения ингибиторов коррозии благодаря образованию прочных пассивных пленок на поверхности стального оборудования. 


\section{Introduction}

During operations of producing wells, oil outputs decrease and volumes of produced formation water increase. Exposure of the downhole equipment to the formation water causes its intense corrosion wear. Equipment corrosion is also influenced by presence of acid gases (hydrogen sulfide and carbon dioxide) in the produced oil. Corrosion reduces mean time between failure of the downhole oil producing equipment and leads to high financial and environmental losses. Chemical equipment protection methods are widely used nowadays; they are based on regulating the electrochemical balance in liquid environments or formation of protective films on metal surfaces of the equipment. A high watercut of wellbore fluids makes chemical protection with corrosion inhibitors very expensive.

\section{Formation Water Composition}

Formation waters of hydrocarbon fields are balanced thermodynamic systems that consist of solutions of various salts and gases. Ionic composition of the produced water in the hydrocarbon fields of Perm Krai is mostly represented by cations $\left(\mathrm{Na}^{+}, \mathrm{K}^{+}, \mathrm{Ca}^{+2}\right.$, $\left.\mathrm{Mg}^{+2}\right)$ and anions $\left(\mathrm{Cl}^{-}, \mathrm{SO}_{4}^{2-}, \mathrm{HCO}_{3}^{-}\right)$. Depending on the genesis of the formation waters, a quantitative content of each ion can vary. Formation waters of hydrocarbon fields typically have high content of $\mathrm{Cl}^{-}$ions - up to $300 \mathrm{~g} / \mathrm{L}$; the origin of chloride ions is salt solutions $\left(\mathrm{KCl}, \mathrm{NaCl}, \mathrm{CaCl}_{2}, \mathrm{MgCl}_{2}\right.$ etc.). The presence of sulfates and bicarbonates is caused by dissolution of carbonate rock $\left(\mathrm{CaCO}_{3}\right.$ and $\left.\mathrm{MgCO}_{3}\right)$ and gypsum $\left(\mathrm{CaSO}_{4}\right)$; the content of these anions changes depending on a certain formation water type and usually does not exceed $3 \mathrm{~g} / \mathrm{L}$.

Apart from salts, formation waters can also contain dissolved acid gases $-\mathrm{H}_{2} \mathrm{~S}$ и $\mathrm{CO}_{2}$, originating from an associated occurrence of hydrocarbons with formation waters. Properties of formation waters also depend on $\mathrm{pH}$ value which can range from 5 to 8 in natural conditions of oil and gas formations occurrence. Presence of each component in the formation waters determines its type and corrosive effect on metals. A detailed analysis of influence of the formation water composition on a metal corrosion rate is provided below.

\section{Influence of Formation Water Ionic Composition on Steel Corrosion Rate}

Corrosion of metals in liquid environments containing dissolved salts has an electrochemical mechanism and occurs at the interface between a metal (electrode) and electrolyte (formation water). It involves formation of adsorption films on metal surfaces - double electric layers (DEL), mostly represented by anions of salts dissolved in electrolytes. The double electric layer at the electrode-electrolyte interface possesses electric resistance and a certain electric capacity corresponding to its molecular thickness. DEL electric properties characterize the degree of chemical interaction between electrode and electrolyte and are used to determine metal corrosion rate employing such methods as, e.g., impedance spectroscopy and voltammetry. Impedance spectroscopy methods consist in supply of a sinusoidal low amplitude excitation signal to the system under research and studying the output response signal [1]. Voltammetry is a method that captures changes over time of the current flowing through the system under study when exposed to voltage [2]. The higher is DEL electrical conductivity, the faster are surface chemical reactions, including metal corrosion. The more is DEL thickness and the less its electrical conductivity, the thicker and the stronger is the passivation film and the lower is the corrosion rate.

The most hazardous type of steel equipment corrosion in oil and gas wells is pitting corrosion. It causes local cavitation of metal, which can lead to premature failure of equipment, while most of the metal surface can still remain intact.

Occurrence and progress of pitting corrosion on metal surfaces in electrolytes occurs when the critical voltage potential of pitting corrosion formation is exceeded. Presence of aggressive anions in electrolytes (normally chlorides) facilitates reduction of pitting corrosion critical potential and acceleration of corrosion processes [3]. In absence of chloride ions, oxide film of stainless steel 304 remains passive until achievement of values of oxygen release voltage potential $(+1.2 \mathrm{~V})$. In $\mathrm{NaCl}$ solution with the concentration of 0.1 mole, pitting starts to occur at the voltage potential of $+0.35 \mathrm{~V}$ (Fig. 1). In $\mathrm{Na}_{2} \mathrm{SO}_{4}$ solution with the concentration of 1 mole, pitting does not occur, which confirms the fact that pitting corrosion is mostly caused by presence of chloride ions [4].

As the content of chloride ions in electrolytes increases, pitting corrosion voltage potential becomes significantly lower and steel corrosion accelerates (Fig. 2) [5].

There are many mechanisms of pitting occurrence, with the following basic features [6-12]:

1) at the initial stage, anions from electrolytes concentrate on the passive film surface

2) at the following stage, anions destroy or dissolve the passive film

3) after initiation, current density in the pitting growth focus significantly increases due to relatively small size of pitting surface vs. intact metal surface. 
As the pitting and its volume grow, cations of dissolved metal remain inside it and don't diffuse out from porous products of corrosion. As a result, the accumulated metal cations undergo hydrolysis and acidity grows inside the pitting (Fig. 3, a). Besides, electrode potential above the pitting is more active than on the adjacent surface (Fig. 3, $b$ ) [13].

Thus, occurrence of pitting corrosion includes formation of acid corrosive internal electrolyte. The system that is formed is stable and stimulates constant further growth of pitting.

Presence of sulfate ions increases pitting corrosion voltage potential, which slows it down [14-17] (Fig. 4).

$\mathrm{HCO}_{3}^{-}$anion facilitates deceleration of corrosion processes through interaction with calcium cations and forming calcium bicarbonate $\mathrm{Ca}\left(\mathrm{HCO}_{3}\right)_{2}$. Calcium bicarbonate is the cheapest cathode screening inhibitor of steel corrosion and, owing to formation of insoluble calcium carbonate which precipitates on metal surface, is used in water supply systems.

Hydrogen sulfide $\mathrm{H}_{2} \mathrm{~S}$ is an aggressive gas which dissolves in water and forms weak acid that causes corrosion of metals with formation of sulfides, which play the role of cathode in regard to iron and form a galvanic pair with it, which leads to quick deterioration of metal structures $[18,19]$. Hydrogen sulfide speeds up the anode reaction of iron ionization:

$$
\mathrm{Fe}+\mathrm{H}_{2} \mathrm{~S}+\mathrm{H}_{2} \mathrm{O} \rightarrow \mathrm{Fe}(\mathrm{HS})_{\mathrm{adc}}^{-}+\mathrm{H}_{3} \mathrm{O}^{+} .
$$

In simultaneous presence of hydrogen sulfide and acids in the solution, corrosivity of both components increases drastically [20, 21]. Corrosion rate in $1 \mathrm{~N} \mathrm{HCI}$ solution sharply increases as the temperature rises. Hydrogen sulfide mostly accelerates anode process of corrosion than the cathode process [22] due to formation of a surface compound $\left(\mathrm{FeHS}^{-}\right)_{\text {ads }}$ that is a catalyst of anode reaction of metal ionization [23-28].

Carbon and low-alloy steels that are most commonly used in construction of oil and gas pipelines are prone to corrosion in $\mathrm{CO}_{2}$ containing environments. Carbon dioxide solution in water phase forms carbon acid which causes steel corrosion:

$$
\mathrm{CO}_{2}+\mathrm{H}_{2} \mathrm{O} \leftrightarrow \mathrm{H}_{2} \mathrm{CO}_{3} .
$$

The mechanism of iron dissolution in carbon acid [29] is represented by cathode (3), (4), (5) and anode (6) reactions. At ambient $\mathrm{pH}$ equal to $6, \mathrm{H}_{2} \mathrm{CO}_{3}(2)$ and $\mathrm{HCO}_{3}^{-}$decompose (3).

$$
\begin{gathered}
2 \mathrm{H}_{2} \mathrm{CO}_{3}+2 \mathrm{e}^{-} \rightarrow \mathrm{H}_{2}+2 \mathrm{HCO}_{3}^{-} \\
2 \mathrm{HCO}_{3}^{-}+2 \mathrm{e}^{-} \rightarrow \mathrm{H}_{2}+2 \mathrm{CO}_{3}^{2-} \\
2 \mathrm{H}^{+}+2 \mathrm{e}^{-} \rightarrow \mathrm{H}_{2} \\
\mathrm{Fe} \rightarrow \mathrm{Fe}^{2+}+2 \mathrm{e}^{-}
\end{gathered}
$$

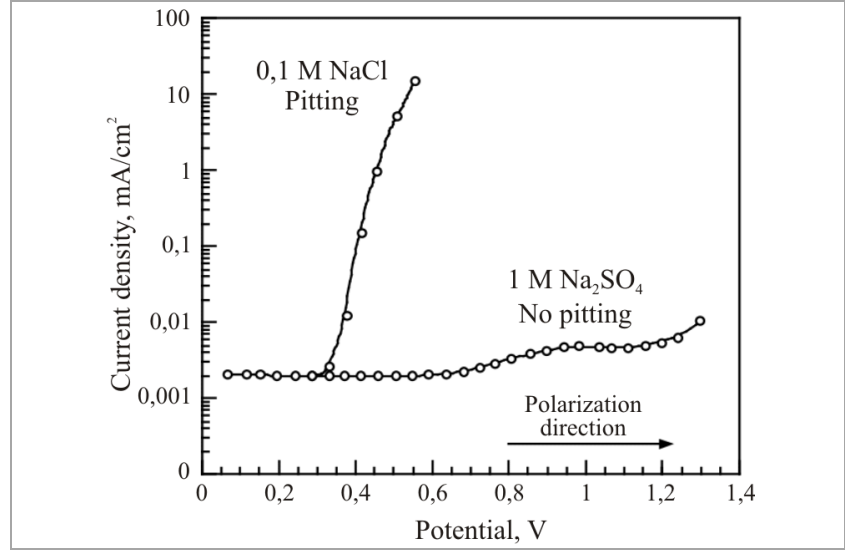

Fig. 1. Polarization curves for stainless steel in 0.1 mole $\mathrm{NaCl}$ solution and 1 mole $\mathrm{Na}_{2} \mathrm{SO}_{4}$ solution [4]

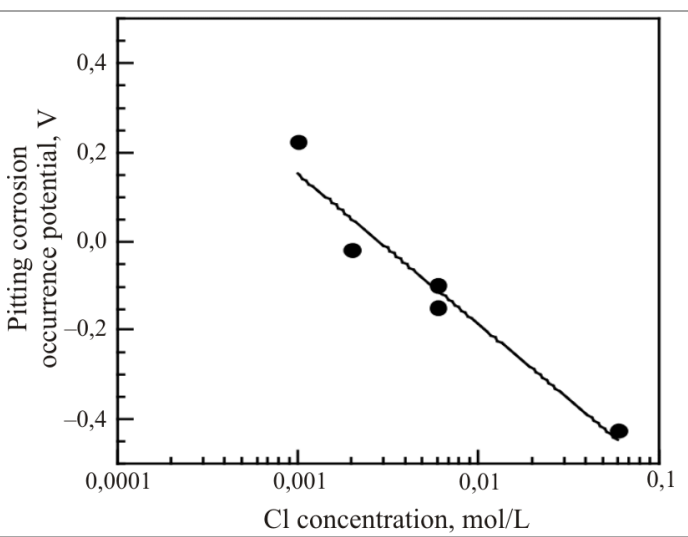

Fig. 2. Impact of chloride ions content on pitting corrosion occurrence potential [5]

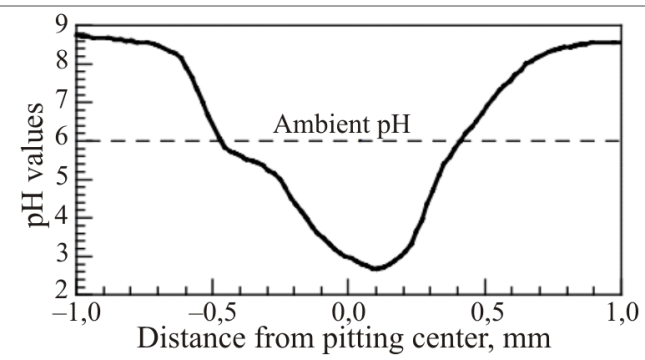

$a$

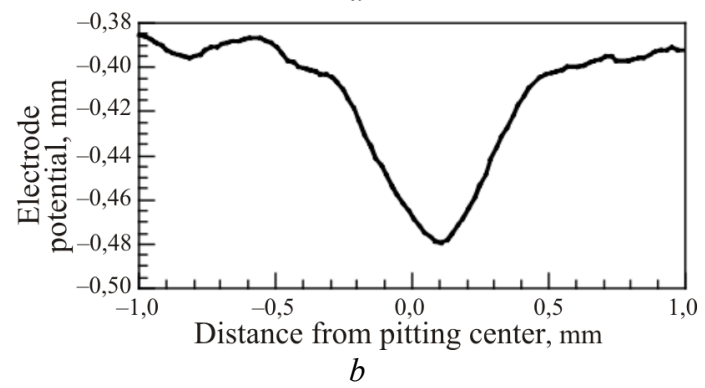

Fig. 3. Change of $\mathrm{pH}(a)$ and electrode potential $(b)$ against growing pitting on steel surface in weak $\mathrm{NaCl}$ solution [13] 
As a result of these processes, a corrosive layer forms on steel surface. Properties of this layer impact steel corrosion rate in $\mathrm{CO}_{2}$ water solutions. Some of the studies suggest that low-soluble iron carbonate sediment $\mathrm{FeCO}_{3}$ can form protective layers [29-34], which is explained by equations (7), (8) and $(9)[35,36]$ :

$$
\begin{gathered}
\mathrm{Fe}^{2+}+\mathrm{CO}_{3}^{2-} \rightarrow \mathrm{FeCO}_{3} \\
\mathrm{Fe}^{2+}+2 \mathrm{HCO}_{3}^{-} \rightarrow \mathrm{Fe}\left(\mathrm{HCO}_{3}\right)_{2} \\
\mathrm{Fe}\left(\mathrm{HCO}_{3}\right)_{2} \rightarrow \mathrm{FeCO}_{3}+\mathrm{CO}_{2}+\mathrm{H}_{2} \mathrm{O}
\end{gathered}
$$

However, the protective layer formed by $\mathrm{FeCO}_{3}$ sediment is porous and fragile, and only slightly reduces corrosion rate due to the reduction of mass transfer between corrosive medium and clean surface of steel [37].

If $\mathrm{FeCO}_{3}$ protective film forms on steel surface, then emergence of the second capacity arch on Nyquist plot or second time constant on Bode plot can be expected [37]. However, this is not observed on impedance plots (Fig. 5) [38]. This is due to formation of $\mathrm{FeCO}_{3}$ porous thin layer with resistance far lower than charge transfer resistance $[39,40]$.

Increase of capacity values over time (loop diameter increase) is related to the increase in iron carbonate sedimentation area on sample surface, which is accompanied by increasing charge transfer resistance [41].

Ambient $\mathrm{pH}$ influence has been studied in [42], which concluded that decrease of ambient $\mathrm{pH}$ from 8 to 2 causes a reduction of charge transfer resistance $\left(R_{c t}\right)$ by more than two times, which suggests an increase in corrosion rate in acid environments (Fig. 6).

The content of various salts in formation waters contributes to the complexity of corrosion processes occurring in real conditions. Presence of aggressive environments can accelerate corrosion in some instances, but sometimes can slow it down. The conducted research of steel corrosion in formation water analogue with various levels of chloride and sulfate ions and hydrogen sulfide led to the following conclusions [43]:

- presence of sulfate ions in electrolytes facilitates steel surface passivation, whereas hydrogen sulfide content up to $150 \mathrm{mg} / \mathrm{L}$ improves passivation, which is caused by formation of two different passivation products (iron oxides and sulfides) that inhibit anode oxidation of steel;

- content of chloride ions in water from 1 to $40 \mathrm{~g} / \mathrm{L}$ and hydrogen sulfide up to $150 \mathrm{mg} / \mathrm{L}$ does not reduce corrosion rate;

- at the levels of content of chloride ions in water from $160 \mathrm{~g} / \mathrm{L}$, presence of hydrogen sulfide does not contribute to development of corrosion, which is caused by prevalence of chloride ions in corrosion reactions.

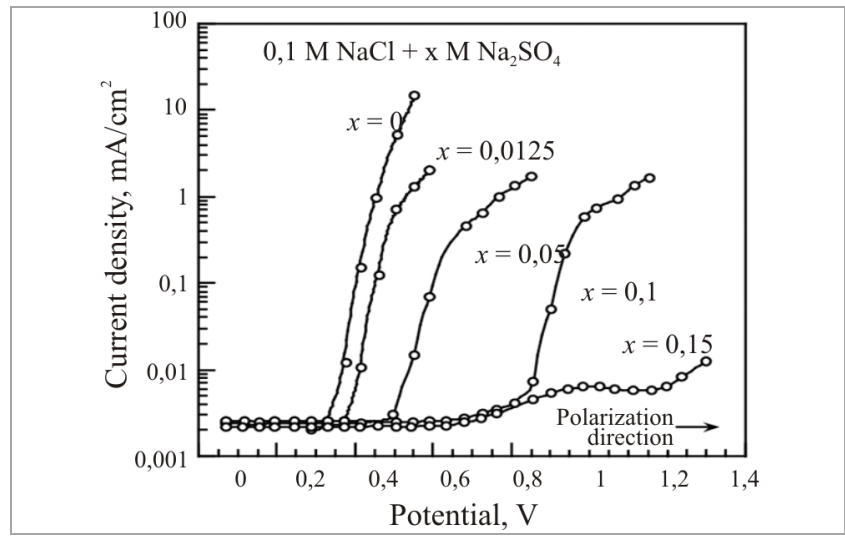

Fig. 4. Impact of sodium sulfate concentration on pitting corrosion occurrence potential on stainless steel 304 in $\mathrm{NaCl}$ solution

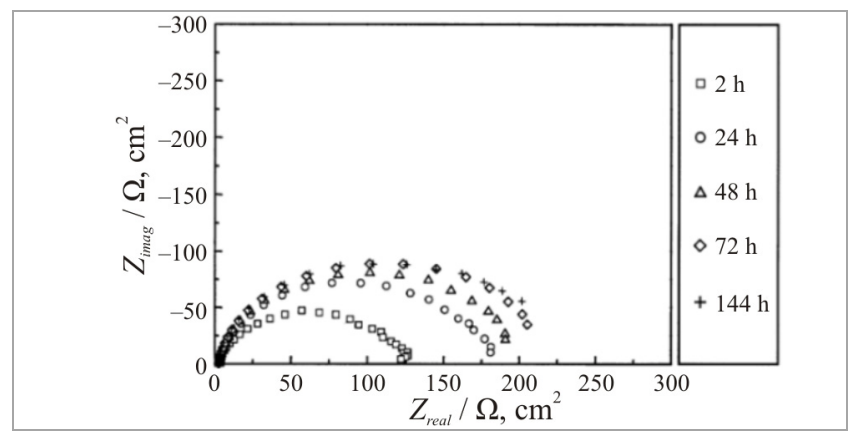

Fig. 5. Impedance diagram for steel after curing in $\mathrm{CO}_{2}$ solution during 2, 24, 48, 72 and $144 \mathrm{~h}[38]$

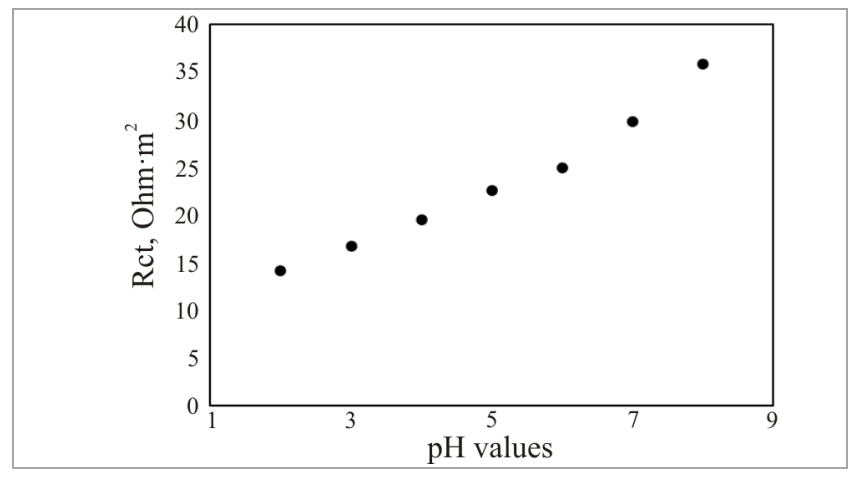

Fig. 6. Impact of ambient $\mathrm{pH}$ on charge transfer resistance $R_{c t}$ on steel surface in $1 \mathrm{~N} \mathrm{HCl}$ solution

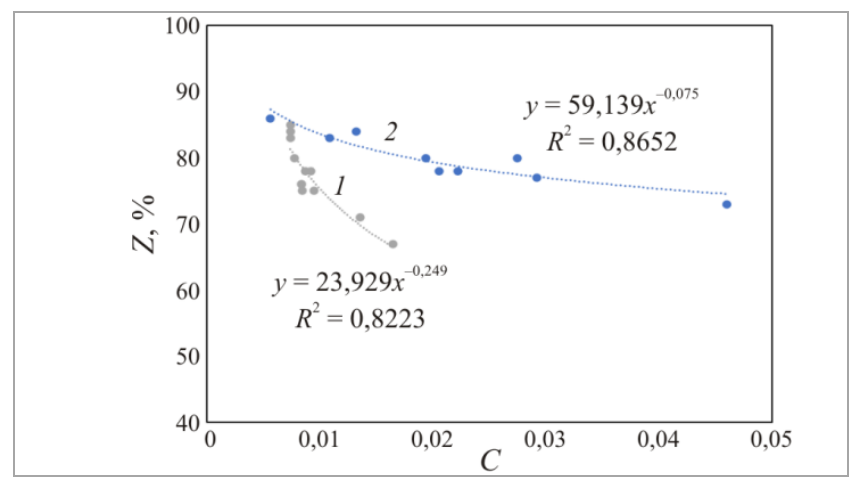

Fig. 7. Impact of anion content on effectiveness of corrosion inhibitors: $1-\mathrm{Cl}^{-}$content more than $60,000 \mathrm{mg} / \mathrm{L}$; $2-\mathrm{Cl}^{-}$content less than $60,000 \mathrm{mg} / \mathrm{L}$ 
Results of research of corrosion inhibitor effectiveness and formation water properties in Perm Krai fields

\begin{tabular}{|c|c|c|c|c|c|c|c|c|c|c|c|c|c|c|}
\hline $\begin{array}{l}\text { Sr. } \\
\text { No. }\end{array}$ & Well & $\begin{array}{c}\text { Effective } \\
\text { ness, } \%\end{array}$ & $\begin{array}{l}\mathrm{H} 2 \mathrm{~S} \\
\mathrm{mg} / \mathrm{L}\end{array}$ & $\begin{array}{l}\mathrm{CO} 2 \\
\mathrm{mg} / \mathrm{L}\end{array}$ & $\mathrm{pH}$ & $\rho, \mathrm{g} / \mathrm{cm} 3$ & $\begin{array}{c}\text { Total } \\
\text { salinity, } \\
\text { g/L }\end{array}$ & $\begin{array}{c}\mathrm{HCO}_{3}^{-}, \\
\mathrm{mg} / \mathrm{L}\end{array}$ & $\begin{array}{c}\mathrm{SO}_{4}^{2-} \\
\mathrm{mg} / \mathrm{L}\end{array}$ & $\mathrm{Cl}-, \mathrm{mg} / \mathrm{L}$ & $\begin{array}{l}\mathrm{Ca} 2+, \\
\mathrm{mg} / \mathrm{L}\end{array}$ & $\begin{array}{c}\mathrm{Mg} 2+ \\
\mathrm{mg} / \mathrm{L}\end{array}$ & $\begin{array}{c}\mathrm{K}++\mathrm{Na}+ \\
\mathrm{mg} / \mathrm{L}\end{array}$ & C \\
\hline \multicolumn{15}{|c|}{ Group 1} \\
\hline 1 & 934 & 75 & 151.60 & 35 & 6.71 & 1.098 & 143.80 & 210 & 625 & 88300 & 10200 & 2580 & 41885 & 0.0095 \\
\hline 2 & 2606 & 78 & 112.30 & 38 & 6.56 & 1.105 & 155.65 & 190 & 690 & 96000 & 10200 & 2700 & 45873 & 0.0092 \\
\hline 3 & 1299 & 80 & 356.80 & 30 & 6.19 & 1.095 & 145.80 & 183 & 509 & 89900 & 9900 & 2260 & 43003 & 0.0077 \\
\hline 4 & 797 & 83 & 118.50 & 30 & 6.19 & 1.115 & 165.04 & 170 & 580 & 102000 & 10800 & 2950 & 48544 & 0.0074 \\
\hline 5 & 868 & 84 & 98.50 & 30 & 6.46 & 1.114 & 165.04 & 170 & 580 & 102000 & 10800 & 2950 & 48544 & 0.0074 \\
\hline 6 & 922 & 85 & 138.00 & 33 & 7.00 & 1.075 & 108.80 & 270 & 230 & 67600 & 6830 & 2300 & 31906 & 0.0074 \\
\hline 7 & 193 & 76 & 132.00 & 35 & 6.11 & 1.070 & 103.90 & 305 & 230 & 64230 & 6140 & 2078 & 30900 & 0.0083 \\
\hline 8 & 905 & 67 & 206.30 & 35 & 6.23 & 1.108 & 156.40 & 140 & 1440 & 96000 & 10200 & 2950 & 45740 & 0.0165 \\
\hline 9 & 498 & 71 & 132.40 & 50 & 6.58 & 1.115 & 165.00 & 170 & 580 & 102000 & 10800 & 2950 & 48544 & 0.0074 \\
\hline 10 & 241 & 75 & 58.70 & 30 & 6.21 & 1.131 & 193.20 & 122 & 888 & 120000 & 14700 & 3040 & 54228 & 0.0084 \\
\hline 11 & 193 & 76 & 132.00 & 35 & 6.11 & 1.070 & 103.90 & 305 & 230 & 64230 & 6140 & 2078 & 30900 & 0.0083 \\
\hline \multicolumn{15}{|c|}{ Group 2} \\
\hline 1 & 953 & 73 & 98.00 & 35 & 7.32 & 1.057 & 84.02 & 390 & 1950 & 50900 & 6060 & 1500 & 23220 & 0.0460 \\
\hline 2 & 2264 & 77 & 164.10 & 30 & 6.54 & 1.058 & 77.02 & 390 & 950 & 45900 & 5060 & 1500 & 23216 & 0.0292 \\
\hline 3 & 229 & 80 & 4.30 & 35 & 7.00 & 1.049 & 73.33 & 545 & 290 & 43100 & 5083 & 1220 & 24216 & 0.0194 \\
\hline 4 & 335 & 78 & 0.00 & 50 & 6.58 & 1.021 & 35.60 & 240 & 298 & 24283 & 2050 & 450 & 8240 & 0.0222 \\
\hline 5 & 542 & 78 & 53.00 & 15 & 7.06 & 1.046 & 68.30 & 250 & 594 & 41122 & 4609 & 1093 & 20556 & 0.0205 \\
\hline 6 & 508 & 83 & 57.00 & 27 & 7.19 & 1.060 & 95.30 & 162 & 458 & 57105 & 6679 & 1516 & 29126 & 0.0109 \\
\hline 7 & 563 & 84 & 137.80 & 45 & 7.18 & 1.067 & 96.60 & 200 & 589 & 59900 & 6500 & 1700 & 27711 & 0.0132 \\
\hline 8 & 859 & 86 & 67.80 & 35 & 7.36 & 1.066 & 95.90 & 210 & 123 & 59600 & 6570 & 1800 & 27883 & 0.0056 \\
\hline 9 & 1026 & 80 & $\begin{array}{l}75.90 \\
\end{array}$ & 47 & 6.45 & 1.062 & 97.40 & 326 & 1290 & 58900 & 4610 & 1580 & 30676 & 0.0274 \\
\hline
\end{tabular}

\section{Laboratory Data Analysis}

Use of corrosion inhibitors helps slow down electrochemical reactions on steel surfaces. Corrosion inhibitor application effectiveness mostly depends on electrolyte content. In certain instances, presence of dissolved salt ions improves inhibitor effectiveness due to formation of strong passive films on steel equipment surfaces $[44,45]$.

Effectiveness of imidazoline corrosion inhibitor used in Perm Krai oilfields was determined in laboratory conditions using cyclic voltammetry (CVA). Corrosion inhibitor was added to formation water from Perm Krai fields in the concentration of $100 \mathrm{~g} / \mathrm{m}^{3}$. Research results and formation water content are shown in the table (table). The research data has been split into two groups based on chloride ions content in formation waters.

Corrosion inhibitor effectiveness (Z) was determined from the following ratio:

$$
Z=\frac{I_{\mathrm{o}}+I_{\text {in }}}{I_{\mathrm{o}}}
$$

where $I_{\mathrm{o}}$ and $I_{\text {in }}$ - maximum anode current densities before and after addition of inhibitor, respectively.

Laboratory analysis has shown that effectiveness of imidazoline corrosion inhibitor is mostly influenced by anion content ratio $\left(\mathrm{HCO}_{3}^{-}, \mathrm{SO}_{4}^{2-}\right.$ and $\left.\mathrm{Cl}^{-}\right)$in formation water (Fig. 7):

$$
C=\frac{C_{\mathrm{HCO}_{3}^{-}}+C_{\mathrm{SO}_{4}^{2-}}}{C_{\mathrm{Cl}^{-}}},
$$

where $C_{\mathrm{HCO}_{3}^{-}}, \quad C_{\mathrm{SO}_{4}^{2-}} C_{\mathrm{Cl}^{-}}-$weight content of bicarbonate ions, sulfate ions and chloride ions in formation water, respectively.

Based on the results of laboratory analysis, it has been established that at high content of chloride ions, effectiveness of imidazoline corrosion inhibitor mostly depends on the content of bicarbonate and sulfate ions (Fig. 7, curve 1). No evidence of impact of hydrogen sulfide content on inhibitor effectiveness has been obtained, which can be caused by prevalence of chloride ions. For the second group, with lower content of chloride ions, dependence of inhibitor effectiveness on $C$ is more flat; impact of hydrogen sulfide was not observed either.

\section{Conclusion}

Corrosion activity of formation waters in Perm Krai fields is caused by presence of aggressive substances $\left(\mathrm{Cl}^{-}\right.$, $\mathrm{SO}_{4}^{2-}, \mathrm{HCO}_{3}^{-}, \mathrm{H}_{2} \mathrm{~S}$ and $\mathrm{CO}_{2}$ ), each of them having an individual impact on corrosion acceleration. Presence of a mix of aggressive components (chloride ions and hydrogen sulfide) in formation water of Perm Krai fields leads to inhibition of hydrogen sulfide corrosion; chloride corrosion rate also goes down.

Presence of anions of dissolved salts $\left(\mathrm{Cl}^{-}, \mathrm{SO}_{4}^{2-}\right.$, $\left.\mathrm{HCO}_{3}^{-}\right)$and acid gases $\left(\mathrm{H}_{2} \mathrm{~S}, \mathrm{CO}_{2}\right)$ in formation waters 
improves effectiveness of imidazoline corrosion inhibitor in Perm Krai fields owing to formation of strong passive films on steel equipment surfaces.

\section{Acknowledgements}

The author is grateful to his academic supervisor, Associate Professor M.S. Turbakov, for his mentorship and support.

\section{References}

1. Emel'ianova Iu.V., Morozova M.V., Mikhailovskaia Z.A., Buianova E.S. Impedansnaia spektroskopiia: teoriia i primenenie [Impedance spectroscopy: theory and application]. Ed. E.S. Buianova. Ekaterinburg: Ural'skii federal'nyi universitet imeni pervogo Prezidenta Rossii B.N. El'tsina, 2017, 156 p.

2. Kaplan B.Ia., Pats R.G., Salikhdzhanova R.M.-F. Vol'tamperometriia peremennogo toka [Voltammetry of alternating current]. Moscow, 1985, $264 \mathrm{p}$.

3. Engell, H.J., Frankenthal R.P., Kruger J. Passivity of Metals. (Proc. of the Fourth International Symposium on Passivity). The Corrosion Monograph Series. The Electrochemical Society, Inc. Princeton, New Jersey, 1978, 285 p.

4. Leckie H.P., Uhlig H.H. Environmental factors affecting critical potential for pitting in 18-8 stainless steel. J. Electrochem. Soc, 1966, vol. 113, pp. 1262-1267.

5. McCafferty E. A Competitive Adsorption Model for the Inhibition of Crevice Corrosion and Pitting. J. Electrochem. Soc, 1990, vol. 137, pp. 3731-3737.

6. Parkins R.N. Fundamental Aspects of Stress Corrosion Cracking. Eds. R.W. Staehle, A.J. Forty, D. van Rooyen. NACE, Houston, TX, 1969, $361 \mathrm{p}$.

7. Sandoz G. Stress-Corrosion Cracking in High Strength Steels and in Titanium and Titanium Alloys. Ed. B.F. Brown. U.S. Government Printing Office, Washington, DC, 1972, $79 \mathrm{p}$.

8. Beck T.R. The Theory of Stress Corrosion Cracking in Alloys. Ed. J.C. Scully. NATO, Brussels, Belgium, 1971. 64 p.

9. Fujii C.T., Metzbower E.A. Stress-Corrosion Cracking in the HY-130 System. NRL Memorandum Report 2814, Naval Research Laboratory. Washington, DC, 1974.

10. Blackburn M.J., Smyrl W.H., Feeny J.A. Stress-Corrosion Cracking in High Strength Steels and in Titanium and Titanium Alloys. Ed. B.F. Brown. U.S. Government Printing Office, Washington, DC, 1972, $245 \mathrm{p}$.

11. Beavers J.A. Stress-Corrosion Cracking. Ed. R.H. Jones. ASM International, Materials Park, $O H, 1992,211$ p.
12. Uhlig H.H., Revie R.W. Corrosion and Corrosion Control. Chapter 7. John Wiley. New York, NY, 1985

13. Bockris J.O'M., Reddy A.K.N. Modern Electrochemistry. New York, NY: Plenum Press, 1979, vol. $2,1233 \mathrm{p}$.

14. Hyatt M.V., Speidel M.O. Stress-Corrosion Cracking in High Strength Steels and in Titanium and Titanium Alloys. Ed. B.F. Brown, U. S. Government Printing Office, Washington, DC, 1972, $147 \mathrm{p}$.

15. Sprawls D.O., Brown R.H. Fundamental Aspects of Stress Corrosion Cracking. Eds. R.W. Staehle, A.J. Forty, D. van Rooyen. NACE, Houston, TX, 1969, 466 p.

16. Ciaraldi S.W. Stress-Corrosion Cracking. Ed. R.H. Jones. ASM International, Materials Park, OH, 1992, $41 \mathrm{p}$

17. Pugh E.N., Craig J.V., Sedriks A.J. Fundamental aspects of stress corrosion cracking. Eds. R.W. Staehle, A.J. Forty, D. van Rooyen. NACE, Houston, TX, 1969, 118 p.

18. Zheng Yougui, Bruce Brown, and Srdjan Nešić. Electrochemical Study and Modeling of H2 S Corrosion of Mild Steel. Corrosion, 2014, vol. 70, no. 4, pp. 351-365.

19. Vedage $H$. et al. Electrochemical growth of iron sulfide films in H2S-saturated chloride media. Corrosion, 1993, vol. 49, no. 2, pp. 114-121.

20. Stern M. The effect of alloying elements in iron on hydrogen over-voltage and corrosion rate in acid environments. Journal of the Electrochemical Society, 1955, vol. 102, no. 12, pp. 663-668.

21. Wranglen G. Review article on the influence of sulfide inclusions on the corrodibility of $\mathrm{Fe}$ and steel. Corrosion Science, 1969, no. 9, pp. 585-602.

22. Zashchita metallov [Metal protection]. Moscow, 1969, 709 p.

23. Heusler K.E., Cartledge G.H. The Influence of Iodide Ions and Carbon Monoxide on the Anodic Dissolution of Active Iron. Journal of the Electrochemical Society, 1961, vol. 108, no. 8, pp. 732-741.

24. Kabanov B.N., Burstein R.H., Frumkin A.N. Kinetics of electrode processes on the iron electrode. Discussions of the Faraday Society, 1947, no. 1, pp. 259-269.

25. Kabanov B., Leikis D. Rastvorenie i passivatsiia zheleza $\mathrm{v}$ rastvorakh shchelochi [Dissolution and passivation of iron in alkali solutions]. Doklady AN SSSR, 1947, vol. 58, no. 8, pp. 1685-1688.

26. Iofa 3.A., Vei Bao-Min. Vliianie $\mathrm{pH}$ sredy na skorost' korrozii i anodnoe rastvorenie kobal'ta [Influence of $\mathrm{pH}$ on corrosion rate and anode 
dissolution of cobalt]. Zhurnal fizicheskoi khimii, 1962, vol. 36, no. 11, pp. 2558-2667.

27. Bockris J.OM., Drazic D. The kinetics of deposition and dissolution of iron: Effect of alloying impurities. Electrochimica Acta, 1962, vol. 7, no. 3, pp. 293-313.

28. Lorents V., Eikhkorn G. Vliianie granits subzeren i defektov $\mathrm{v}$ kristallicheskoi reshetke na mekhanizm anodnogo rastvoreniia zheleza [The effect of subgrain boundaries and defects in the crystal lattice on the mechanism of anodic dissolution of iron]. Trudy III Mezhdunarodnogo kongressa po korrozii metallov. Moscow: Mir, 1968, vol. 1, pp. 184-187.

29. Ogundele G.I., White W.E. Some observations on corrosion of carbon steel in aqueous environments containing carbon dioxide. Corrosion, 1986, vol. 42, no. 2, pp. 71-78.

30. Nesic S., Nordsveen M., Nyborg R., Stangeland A. A Mechanistic Model for Carbon Dioxide Corrosion of Mild Steel in the Presence of Protective Iron Carbonate Films. Part 1. Theory and Verification. Proceedings of NACE Corrosion 2001. NACE, Houston, TX, 2001, 1040 p.

31. Videm K., Dugstad A. Corrosion of carbon steel in an aqueous carbon dioxide environment, Part 1. Solution effects. $M P, 1989$, vol. 28 , no. 3 .

32. Lopez D.A., Schreiner W.H., Sanchez de S.R., Simison S.N. The influence of carbon steel microstructure on corrosion layers. An XPS and SEM characterization. Applied Surface Science, 2003, vol. 207, pp. 69-85.

33. Johnson M.L., Tomson M.B. Ferrous Carbonate Precipitation Kinetics and Its Impact on $\mathrm{CO}_{2}$ Corrosion. Corroison. NACE: Houston, 1991, vol. 91, 268 p.

34. Xia Z., Chou C., Smialowska Z.S. Pitting Corrosion of Carbon Steel in $\mathrm{CO}_{2}$. - Containing $\mathrm{NaCl}$ Brine. Corrosion, 1989, vol. 45, no. 8, 636 p.

35. Heuer J.K., Stubbings J.F. An XPS characterization of $\mathrm{FeCO}_{3}$ films from $\mathrm{CO}_{2}$ corrosion. Corrosion Science, 1999, vol. 41, pp. 1231-1243.

36. Lide D.R. Handbook of Chemistry and Physics. 79th ed., 1998. CRC Press, Boca Raton, 1999.

37. Moraes de F.D., Shadley J.R., Chen J., Rybicki E. $\mathrm{CO}_{2}$ Corrosion Prediction in Pipe Flow Under $\mathrm{FeCO}_{3}$ Scale-Forming Conditions. Proceedings of NACE. Corrosion. NACE 2000, Orlando, FL, 2000, 30 p.

38. López D., Simison S., de Sánchez S. The influence of steel microstructure on $\mathrm{CO}_{2}$ corrosion. EIS studies on the inhibition efficiency of benzimidazole. Electrochimica Acta, 2003, vol. 48, no. 7 , pp. $845-854$.

39. Hong T., Sun Y.H., Jepson W.P. Study on corrosion inhibitor in large pipelines under multiphase flow using EIS. Corrosion Science, 2002, vol. 44, pp. 101-112.

40. Walter G.W. A review of impedance plot methods used for corrosion performance analysis of painted metals. Corrosion Science, 1986, vol. 26, no. 9, pp. 681-703.

41. Popova A., Raicheva S., Sokolava E., Christov M. Frequency Dispersion of the Interfacial Impedance at Mild Steel Corrosion in Acid Media in the Presence of Benzimidazole Derivatives. Langmuir, 1996, vol. 12, no. 8, pp. 2083-2089.

42. Amin M., El-Rehim Abd S., El-Sherbini E., Bayoumi R. The inhibition of low carbon steel corrosion in hydrochloric acid solutions by succinic acid. Electrochimica Acta, 2007, vol. 52, no. 11, pp. 3588-3600.

43. Bystrova O.N. Vliianie serovodoroda na anodnoe povedenie uglerodistoi stali $\mathrm{v}$ solevykh rastvorakh [The effect of hydrogen sulfide on the anode behavior of carbon steel in saline solutions]. Vestnik Kazanskogo technologicheskogo universiteta, 2011, no. 2, pp. 98-103.

44. Veloz M.A., González I. Electrochemical study of carbon steel corrosion in buffered acetic acid solutions with chlorides and H2S. Electrochimica Acta, 2002, vol. 48(2), pp. 135-144.

45. Choi Y., Nesic S., Ling S. Effect of H2S on the $\mathrm{CO}_{2}$ corrosion of carbon steel in acidic solutions. Electrochimica Acta, 2011, vol. 56, no. 4, pp. 1752-1760.

\section{Библиографический список}

1. Импедансная спектроскопия: теория и применение : учеб. пособие / Ю.В. Емельянова, М.В. Морозова, З.А. Михайловская, Е.С. Буянова; под общ. ред. Е.С. Буяновой; Урал. федер. ун-т. Екатеринбург: Изд-во Урал. ун-та, 2017. - 156 с.

2. Каплан Б.Я., Пац Р.Г., Салихджанова Р.М.-Ф. Вольтамперометрия переменного тока. - М., 1985. $264 \mathrm{c}$.

3. Passivity of metals / H.J. Engell, R.P. Frankenthal, J. Kruger // Proc. of the fourth international symposium on passivity. The Corrosion monograph series. The Electrochemical Society, Inc. Princeton. New Jersey, 1978. - 285 p.

4. Leckie H.P., Uhlig H.H. Environmental factors affecting critical potential for pitting in 18-8 stainless steel // J. Electrochem. Soc. - 1966. - Vol. 113. - P. 1262-1267.

5. McCafferty E. A Competitive Adsorption Model for the Inhibition of Crevice Corrosion and Pitting // J. Electrochem. Soc. - 1990. - Vol. 137. P. 3731-3737.

6. Parkins R.N. Fundamental Aspects of Stress Corrosion Cracking / R.W. Staehle, A.J. Forty, D. van Rooyen, eds. - NACE, Houston, TX, 1969. P. 361 
7. Sandoz G. Stress-corrosion cracking in high strength steels and in titanium and titanium alloys / B.F. Brown, ed. - U.S. Government Printing Office, Washington, DC, 1972. - P. 79.

8. Beck T.R. The Theory of stress-corrosion cracking in alloys / J.C. Scully, ed. - NATO, Brussels, Belgium, 1971. - P. 64.

9. Fujii C.T., Metzbower E.A. Stress-corrosion cracking in the HY-130 System / NRL Memorandum Report 2814, Naval Research Laboratory. Washington, DC, 1974.

10. Blackburn M.J., Smyrl W.H., Feeny J.A. Stresscorrosion cracking in high strength steels and in titanium and titanium alloys / B.F. Brown, ed. U.S. Government Printing Office, Washington, DC, 1972. - P. 245.

11. Beavers J.A. Stress-corrosion cracking / R.H. Jones, ed. - ASM International, Materials Park, OH, 1992. - P. 211.

12. Uhlig H.H., Revie R.W. Corrosion and corrosion control. Chapter 7. John Wiley. - New York, NY, 1985.

13. Bockris J.O'M., Reddy A.K.N. Modern electrochemistry. - New York, NY: Plenum Press, 1979. - Vol. 2. - P. 1233.

14. Hyatt M.V., Speidel M.O. Stress-corrosion cracking in high strength steels and in titanium and titanium alloys / B.F. Brown, ed. - U. S. Government Printing Office, Washington, DC, 1972. - P. 147.

15. Sprawls D.O., Brown R.H. Fundamental aspects of stress corrosion cracking / R.W. Staehle, A.J. Forty, D. van Rooyen, eds. - NACE, Houston, TX, 1969. - P. 466.

16. Ciaraldi S.W. Stress-corrosion cracking / R.H. Jones, ed. - ASM International, Materials Park, OH, 1992. - P. 41.

17. Pugh E.N., Craig J.V., Sedriks A.J. Fundamental aspects of stress corrosion cracking / R.W. Staehle, A.J. Forty, D. van Rooyen, eds. - NACE, Houston, TX, 1969. - P. 118.

18. Zheng Yougui, Bruce Brown, Srdjan Nešić. Electrochemical study and modeling of $\mathrm{H}_{2} \mathrm{~S}$ corrosion of mild Steel // Corrosion. - 2014. - Vol. 70, № 4. P. 351-365.

19. Electrochemical growth of iron sulfide films in $\mathrm{H}_{2} \mathrm{~S}$-saturated chloride media / $\mathrm{H}$. Vedage [et al.] // Corrosion. - 1993. - Vol. 49, № 2. - P. 114-121.

20. Stern M. The effect of alloying elements in iron on hydrogen over-voltage and corrosion rate in acid environments // Journal of the Electrochemical Society. 1955. - Vol. 102, № 12. - P. 663-668.

21. Wranglen G. Review article on the influence of sulfide inclusions on the corrodibility of $\mathrm{Fe}$ and steel // Corrosion Science. - 1969, № 9. P. 585-602.
22. Панасенко В.Ф., Антропов Л.И. Защита металлов. - М., 1969. - 709 с.

23. Heusler K.E., Cartledge G.H. The Influence of iodide ions and carbon monoxide on the anodic dissolution of active iron // Journal of the Electrochemical Society. - 1961. - Vol. 108, № 8. - P. 732-741.

24. Kabanov B.N., Burstein R.H., Frumkin A.N. Kinetics of electrode processes on the iron electrode // Discussions of the Faraday Society. - 1947. - № 1. P. 259-269.

25. Кабанов Б., Лейкис Д.И. Растворение и пассивация железа в растворах щелочи // Доклады АН СССР. - 1947. - Т. 58, № 8. - С. 1685-1688.

26. Йофа 3.А., Вэй Бао-Мин. Влияние рН среды на скорость коррозии и анодное растворение кобальта // Журнал физической химии. - 1962. T. 36, № 11. - С. 2558-2667.

27. Bockris J.OM., Drazic D. The kinetics of deposition and dissolution of iron: effect of alloying impurities // Electrochimica Acta. - 1962. - Vol. 7, № 3. - P. 293-313.

28. Лоренц В., Эйхкорн Т. Влияние границ субзерен и дефектов в кристаллической решетке на механизм анодного растворения железа // Труды III Международного конгресса по коррозии металлов, Москва, 1966. - М., 1968. - Т. 1. - 184 с.

29. Ogundele G.I., White W.E. Some observations on corrosion of carbon steel in aqueous environments containing carbon dioxide // Corrosion. - 1986. Vol. 42, № 2. - P. 71-78.

30. Proceedingsof NACE Corrosion/2001 S. Nesic, M. Nordsveen, R. Nyborg, A. Stangeland. NACE, Houston, TX, 2001. - P. 1040.

31. Videm K., Dugstad A. Corrosion of carbon steel in an aqueous carbon dioxide environment, Part 1. Solution effects // MP. - 1989. - Vol. 28, № 3.

32. The influence of carbon steel microstructure on corrosion layers. An XPS and SEM characterization / D.A. Lopez, W.H. Schreiner, S.R. Sanchez de, S.N. Simison // Applied Surface Science. - 2003. Vol. 207. - P. 69-85.

33. Johnson M., Tomson M. Proceedings of NACE Corrosion. - NACE, Houston, TX, 1991. - № 268.

34. Xia Z., Chou C., Smialowska Z.S. Pitting Corrosion of Carbon Steel in $\mathrm{CO}_{2}$. - Containing $\mathrm{NaCl}$ Brine // Corrosion. - 1989. - Vol. 45, № 8. - 636 p.

35. Heuer J.K., Stubbings J.F. An XPS characterization of $\mathrm{FeCO} 3$ films from $\mathrm{CO}_{2}$ corrosion // Corrosion Science. - 1999. - Vol. 41. - P. 1231-1243.

36. Lide D.R. Handbook of Chemistry and Physics. - 79th ed., 1998. CRC Press, Boca Raton, 1999.

37. $\mathrm{CO}_{2}$ corrosion prediction in pipe flow under $\mathrm{FeCO}_{3}$ scale-forming conditions / F.D. Moraes 
de, J.R. Shadley, J. Chen, E. Rybicki // Proceedings of NACE. Corrosion. NACE. - Orlando, FL, 2000. $-30 \mathrm{p}$.

38. López D., Simison S., de Sánchez S. The influence of steel microstructure on $\mathrm{CO} 2$ corrosion. EIS studies on the inhibition efficiency of benzimidazole // Electrochimica acta. - 2003. Vol. 48, № 7. - P. 845-854.

39. Hong T., Sun Y.H., Jepson W.P. Study on corrosion inhibitor in large pipelines under multiphase flow using EIS // Corrosion Science. - 2002. Vol. 44. - P. 101-112.

40. Walter G.W. A review of impedance plot methods used for corrosion performance analysis of painted metals // Corrosion Science. - 1986. Vol. 26, № 9. - P. 681-703.

41. Frequency Dispersion of the interfacial impedance at mild steel corrosion in acid media in the Presence of Benzimidazole Derivatives /
A. Popova, S. Raicheva, E. Sokolava, M. Christov // Langmuir. - 1996. - Vol. 12, № 8. - P. 2083-2089.

42. The inhibition of low carbon steel corrosion in hydrochloric acid solutions by succinic acid / M. Amin, S. Abd El-Rehim, E. El-Sherbini, R. Bayoumi // Electrochimica Acta. - 2007. - Vol. 52, № 11. P. 3588-3600.

43. Быстрова О.Н. Влияние сероводорода на анодное поведение углеродистой стали в солевых растворах // Вестник Казанского Технологического Университета. - 2011. - № 2. - С. 98-103.

44. Veloz M.A., González I. Electrochemical study of carbon steel corrosion in buffered acetic acid solutions with chlorides and $\mathrm{H} 2 \mathrm{~S} / /$ Electrochimica Acta. - 2002. - Vol. 48, № 2. - C. 135-144.

45. Choi Y., Nesic S., Ling S. Effect of $\mathrm{H}_{2} \mathrm{~S}$ on the $\mathrm{CO} 2$ corrosion of carbon steel in acidic solutions // Electrochimica Acta. - 2011. - Vol. 56, № 4. P. 1752-1760.

Please cite this article in English as:

Ladygin A.N. Influence of anionic composition and acid gas content in formation waters of Perm Kray fields on corrosion inhibitors efficiency. Perm Journal of Petroleum and Mining Engineering, 2020, vol.20, no.2, pp.192-200. DOI: 10.15593/2224-9923/2020.2.9

Просьба ссылаться на эту статью в русскоязычных источниках следующим образом:

Ладыгин А.Н. Влияние анионного состава и содержания кислых газов в пластовых водах месторождений Пермского края на эффективность ингибиторов коррозии // Вестник Пермского национального исследовательского политехнического университета. Геология. Нефтегазовое и горное дело. - 2020. - Т.20, №2. - С.192-200. DOI: $10.15593 / 2224-9923 / 2020.2 .9$ 